\title{
Edukasi HIV/AIDS “Gerakan 1000 Remaja Millenial Peduli Odha" (Gerserha) di MA Al-Mukhtariyah Kabupaten Bandung Barat
}

\author{
Ami Kamila*1, Anzhar Ismail ${ }^{2}$ \\ ${ }^{1}$ Program Studi Sarjana Kebidanan, Sekolah Tinggi Ilmu Kesehatan 'Aisyiyah Bandung, \\ Jl. KH. Ahmad Dahlan Dalam No. 6 Kota Bandung 40264 Telp : (022) 7312423 \\ ${ }^{2}$ Komisi Penanggulangan AIDS Kabupaten Bandung Barat, PMI Kabupaten Bandung Barat, \\ Jl. Raya Batujajar, Giriasih Kabupaten Bandung Barat 40561 \\ *e-mail: bidankamila@gmail.com
}

\begin{abstract}
HIV/AIDS data in West Bandung Regency until July 2019 showed that there were 379 cases of HIV / AIDS with 56 new cases. As many as 53\% of them are caused by free sexual behavior, 33\% are found in the homosexual community and become the second highest after heterosexuals. The three zero program needs to be supported by innovative and ongoing efforts through increasing knowledge in adolescents using counseling to prevent the spread of HIV/AIDS infection early on. 1000 Millennial Youth Care Concerns PLWHA (GERSERHA) Movement is expected to increase adolescent knowledge about Reproductive Health and HIV / AIDS so as to prevent free sex and prevent HIV/AIDS. Activities carried out in the form of counseling using various media. The test is carried out before and after the activity which is one form of evaluation of this activity. Knowledge test results showed a significant increase from the average pre-test results of 63.8 and post-test 89.4. This shows that counseling activities are effective in increasing students' knowledge about reproductive health and HIV / AIDS $(p<0.005)$.
\end{abstract}

Keywords: Reproductive Health, HIV/AIDS, Adolescents

\begin{abstract}
Abstrak
Data HIV/AIDS di Kabupaten Bandung Barat hingga Juli 2019, terdapat 379 kasus HIV/AIDS dengan 56 kasus baru. Sebanyak 53\% diantaranya disebabkan oleh perilaku hubungan seksual bebas, 33\% ditemukan pada komunitas homoseksual dan menjadi tertinggi kedua setelah heteroseksual. Program three zero perlu didukung dengan upaya inovatif dan berkesinambungan melalui peningkatan pengetahuan pada usia remaja melalui penyuluhan untuk mencegah penyebaran infeksi HIV/AIDS sejak dini. Gerakan 1000 Remaja Millenial Peduli ODHA (GERSERHA) ini diharapkan dapat meningkatkan pengetahuan remaja mengenai Kesehatan Reproduksi dan HIV/AIDS sehingga mencegah perilaku seks bebas dan dapat mencegah HIV/AIDS. Kegiatan dilakukan dengan bentuk penyuluhan menggunakan berbagai media. Tes dilaksanakan sebelum dan sesudah kegiatan yang merupakan salah satu bentuk evaluasi dari kegiatan ini. Hasil tes pengetahuan menunjukkan adanya peningkatan yang signifikan dari rata-rata hasil pre-test 63,8 dan post-test 89,4. Hal ini menunjukkan bahwa kegiatan penyuluhan efektif meningkatkan pengetahuan siswa tentang Kespro dan HIV/AIDS ( $p<$ 0,005).
\end{abstract}

Kata kunci: Kesehatan Reproduksi, HIV/AIDS, Remaja

\section{PENDAHULUAN}

Masalah mengenai HIV/AIDS masih menjadi tantangan khususnya di Indonesia. Walaupun banyak penelitian mengenai infeksi ini, tetapi hal ini masih belum bisa menghentikan atau mengurangi penyebaran infeksi HIV/AIDS di masyarakat. Sampai dengan bulan Juni 2018, jumlah kumulatif infeksi HIV/AIDS yang dilaporkan mencapai 301.959 jiwa (57\% dari estimasi ODHA jumlah orang dengan HIV/AIDS tahun 2018 sebanyak 640.443 jiwa) dan paling banyak ditemukan pada kelompok umur usia produktif antara 20-49 tahun. Jawa Barat naik peringkat menjadi provinsi tertinggi ketiga setelah DKI Jakarta (55.099) dan Jawa Timur (43.399) dengan jumlah 31.293 diikuti oleh Papua (30.699) dan Jawa Tengah (24.757) (Depkes RI, 2018).

Remaja saat ini cenderung menghadapi tantangan kesehatan dan sosial sendiri. Sebagai contoh, remaja memulai hubungan seksual yang berisiko padahal mereka belum memiliki pengetahuan serta keterampilan yang benar untuk melindungi diri mereka sendiri dari berbagai 
risiko kesehatan reproduksi, seperti kehamilan yang tidak diinginkan, aborsi, infeksi menular seksual dan bahkan HIV/AIDS. WHO mulai mempromosikan Kesehatan Seksual dan Reproduksi Remaja untuk menghadapi tantangan serta melindungi remaja dan meningkatkan sistem perawatan kesehatan sehingga mampu menyediakan layanan kesehatan yang ramah untuk remaja (WHO, 2019).

World Health Organization (WHO) mengartikan remaja adalah individu yang masuk dalam kelompok usia 10-19 tahun. Di dunia diperkirakan kelompok remaja berjumlah 1,2 milyar atau $18 \%$ dari jumlah penduduk dunia. Sedangkan di Indonesia ada beberapa definisi remaja berdasarkan batas usia, diantaranya menurut Peraturan Menteri Kesehatan RI Nomor 25 tahun 2014, remaja adalah penduduk yang rentang usinya antara 10-18 tahun sedangkan menurut Badan Kependudukan dan Keluarga Berencana (BKKBN), rentang usia remaja dari usia 10-24 tahun dan belum menikah (Kemenkes, 2014).

Fase perkembangan pada masa remaja harus menjadi pusat perhatian, karena pada masa ini merupakan masa transisi dari anak-anak ke usia dewasa. Remaja akan merasa bukan anakanak tetapi mereka belum mampu memegang tanggung jawab seperti orang dewasa. Pada masa ini, remaja akan mengalami peralihan masa dari anak dengan dewasa dan akan mengalami perkembangan semua aspek/fungsi untuk memasuki masa dewasa Oleh karena itu, perlu kiranya pada masa seperti ini remaja diberikan pengetahuan yang dapat menjadi bekal mereka supaya mampu berperilaku yang dapat dipertanggungjawabkan.

Gerakan 1000 Remaja Peduli ODHA (Gerserha), bukan hanya bertujuan supaya remaja tidak memiliki pandangan negatif atau diskriminasi terhadap Odha sehingga menutup diri dari pengetahuan mengenai HIV/AIDS, tetapi gerakan ini juga bertujuan supaya nantinya remaja akan mampu untuk melakukan pencegahan penyebaran HIV/AIDS sehingga dapat mendorong masyarakat disekitarnya untuk hidup sehat tanpa virus HIV. Gerakan ini diprakarsai oleh Kemensos yang telah lebih dulu mengukuhkan 1000 sahabat peduli ODHA yang diharapkan mampu menjadi mitra pemerintah dalam menanggulangi HIV/AIDS di masyarakat (Kementerian Sosial RI, 2018).

Kabupaten Bandung Barat merupakan kabupaten yang terdiri dari 16 Kecamatan, dimana menurut hasil penelitian Kamila (2017), hanya 6 Kecamatan yang terjaring oleh Lembaga Swadaya Masyarakat (LSM) dan Kelompok Dampingan Sebaya (KDS) khususnya untuk komunitas Lelaki yang berhubungan Seks dengan Lelaki (LSL) (Kamila et al., 2017). Berdasarkan analisis situasi Komisi Penanggulangan AIDS (KPA) di Kabupaten Bandung Barat hingga Juli 2019, terdapat 379 kasus HIV/AIDS dengan 56 kasus baru. Sebanyak 53\% diantaranya disebabkan oleh perilaku hubungan seksual bebas, dimana 52\% terjadi pada usia 21-29 tahun dan 36\% ditemukan pada komunitas homoseksual atau gay yang juga menjadi pemicu penularan HIV/AIDS dan menjadi tertinggi kedua setelah heteroseksual. Menurut usia, jumlah kasus HIV/AIDS pada usia 20-24 tahun menjadi tertinggi kedua yaitu sebanyak $23 \%$. Hal ini menjadi indikasi bahwa pada usia remaja yang belum menikah, mereka telah melakukan aktifotas seksual yang berisiko (KPA Kabupaten Bandung Barat, 2019).

Usia remaja yang juga merupakan masa kritis dimana akan muncul kecenderungan untuk mencoba hal baru yang belum pernah dilakukan tanpa dibekali dengan ilmu yang sesuai, akan menjadi rentan untuk mencoba perilaku yang berisiko tanpa mengetahui akibatnya. Hal ini menjadi tantangan bagi KPA dan tenaga pendidik khususnya untuk menggerakkan remaja, selain mengurangi diskriminasi pada ODHA, gerakan ini juga diharapkan dapat menjadi salah satu upaya pencegahan penyebaran infeksi HIV/AIDS secara komrehensif mulai dari usia remaja.

Beberapa penelitian menyebutkan bahwa penyuluhan berpengaruh pada peningkatan pengetahuan remaja, salah satunya adalah penelitian yang dilakukan oleh Frisa (2013) dengan menggunakan metode quasi eksperimen menunjukkan bahwa terdapat perbedaan yang bermakna antara skor sebelum penyuluhan dengan skor setelah penyuluhan dengan nilai signifikan sebesar $0,000(\mathrm{p}<0,05)$ (Buzarudina, 2013). Untuk mencapai keberhasilan program three zero, yaitu 1) Zero new infection; 2) Zero AIDS Related Deaths dan 3) Zero discrimination, perlu adanya upaya 
inovatif dan berkesinambungan dengan peningkatan pengetahuan mengenai kesehatan reproduksi dan HIV/AIDS pada usia remaja melalui penyuluhan untuk mencegah penyebaran infeksi tersebut sejak dini. Melalui kegiatan ini diharapkan dapat memperkenalkan dan menginformasikan berbagai pengetahuan serta memberikan wawasan dan pemahaman tentang pengetahuan dasar dalam penanggulangan HIV/AIDS. Selain itu, dapat meningkatkan pengetahuan tentang HIV/AIDS secara komprehensif khususnya pada usia remaja.

\section{METODE}

Untuk mencapai tujuan dan target yang diharapkan, kegiatan yang dilaksanakan adalah dengan melaksanakan penyuluhan mengenai Kesehatan Reproduksi Remaja dan HIV/AIDS, meliputi pengertian, cara penularan, cara pencegahan, pemeriksaan, dan pengobatan. Penyuluhan diberikan oleh pelaksana PkM bersama-sama dengan anggota mahasiswa dan didampingi oleh KPA Kabupaten Bandung Barat dengan menggunakan media penyuluhan berupa Powerpoint, lembar balik, leaflet dan Video. Pre test dan post test dilaksanakan sebelum dan sesudah kegiatan untuk mengetahui peningkatan pengetahuan remaja terhadap materi yang sudah disampaikan.

\section{Langkah-langkah Kegiatan} berikut :

Tahapan pelaksanaan kegiatan ini dapat digambarkan dengan langkah-langkah sebagai

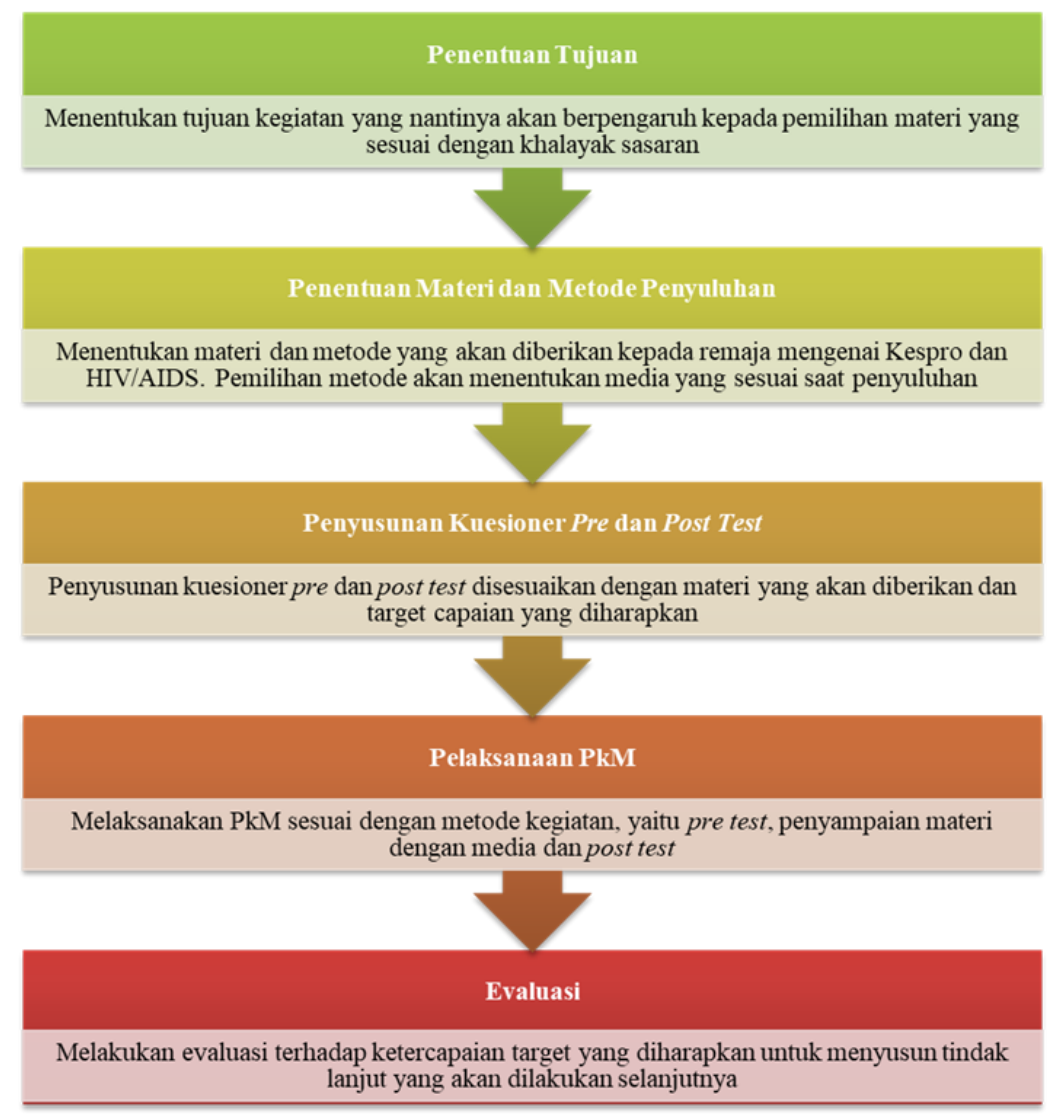

Gambar 1. Langkah-langkah Pelaksanaan Kegiatan Sumber : Kamila, 2019

Persiapan kegiatan, meliputi kegiatan koordinasi dengan Pusat Informasi dan Konseling Remaja (PIKR) Kecamatan Cihampelas untuk melakukan perizinan dan survei tempat pada pihak sekolah MA Al-Mukhtariyah Mande; Persiapan alat dan bahan serta akomodasi; dan Persiapan tempat untuk pelaksanaan pendidikan kesehatan (penyuluhan) melalui koordinasi dengan PIKR Kecamatan Cihampelas. 
Kegiatan penyuluhan atau pendampingan pendidikan kesehatan, meliputi : Pelaksanaan pre test dibantu dibagikan oleh PIKR kepada siswa sesuai perhitungan jumlah sampel dengan prosedur Simple Random Sampling, karena populasi bersifat homogen, sehingga didapatkan jumlah sampel 100 siswa/i yang lebih dulu memasuki ruang aula; Pembukaan dan perkenalan dengan siswa/i MA Al-Mukhtariyah Mande yang menjadi sasaran kegiatan, sebelumnya dibuka dengan sambutan dari perwakilan pihak sekolah dan Ketua Pelaksana KPA Kabupaten Bandung Barat; Penyuluhan diawali mengenai Kesehatan Reproduksi Remaja, kemudian dilanjutkan dengan materi mengenai HIV/AIDS. Kegiatan penyuluhan diselingi oleh ice breaking dan pemutaran Video dari PIKR mengenai Kesehatan Reproduksi dan HIV/AIDS; dan Sesi diskusi/tanya jawab dengan peserta. Peserta tampak antusia mengikuti kegiatan tersebut.

Penutupan, pada sesi ini kegiatan meliputi Pemberian door prize bagi peserta yang memberikan pertanyaan dan menjawab pertanyaan dengan benar serta yang mendapatkan skor baik pada pre dan post test dan Memberikan hasil kegiatan kepada media, evaluasi kegiatan dengan PIKR dan KPA.

\section{HASIL DAN PEMBAHASAN}

Kegiatan ini merupakan kerjasama antara Sekolah Tinggi Ilmu Kesehatan 'Aisyiyah Bandung dengan Komisi Penanggulangan AIDS (KPA) dan Pusat Informasi dan Konseling Remaja (PIKR) Kabupaten Bandung Barat. Kegiatan ini diikuti oleh 195 siswa/i kelas 10 - 12 MA AlMukhtariyah Mande. Kegiatan pendidikan kesehatan (penyuluhan) mengenai Kesehatan Reproduksi Remaja dan HIV/AIDS ini secara umum berjalan dengan lancar. Program pendidikan kesehatan penyuluhan ini dimulai perdana di MA Al-Mukhtariyah Mande yang selanjutnya akan roadshow ke sekolah-sekolah yang ada di Kabupaten Bandung Barat.

Pihak sekolah terutama Kepala Sekolah memberikan apresiasi pada kegiatan ini, dimana memang saat ini masyarakat umumnya dan khususnya remaja sangat membutuhkan pendidikan kesehatan mengenai Kesehatan Reproduksi Remaja dan HIV/AIDS untuk mencegah terjadinya perilaku menyimpang yang dapat menimbulkan risiko yang tidak diinginkan. Persiapan tempat dilakukan oleh PIKR Kecamatan Cihampelas yang salah satunya juga merupakan duta Genre di sekolah tersebut.

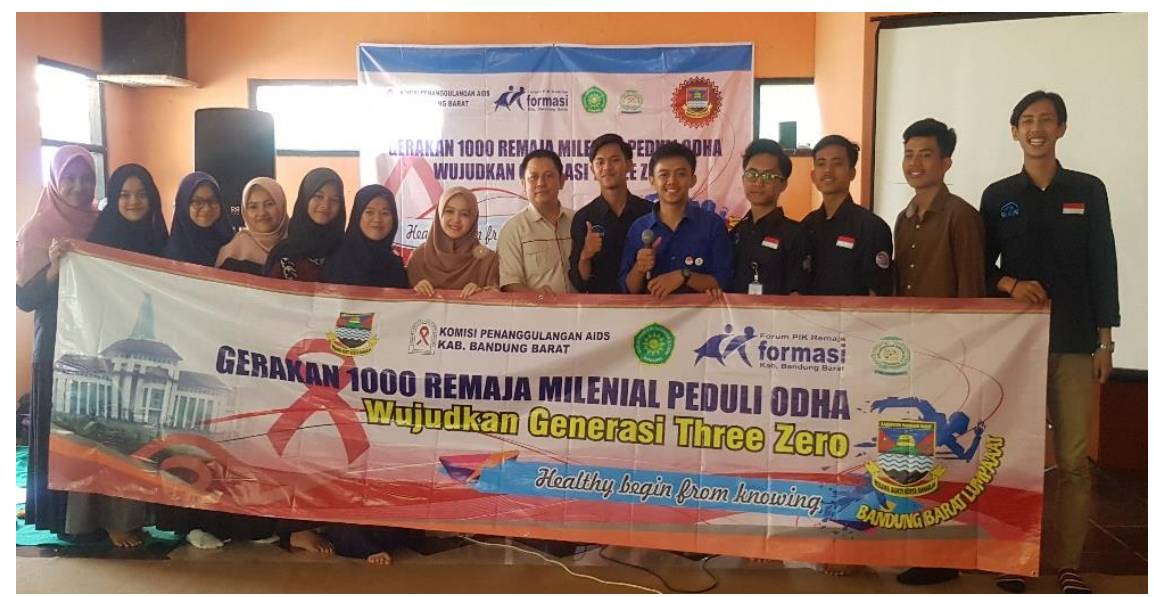

Gambar 2. Tim Pelaksana Kegiatan bersama KPA dan PIKR Kabupaten Bandung Barat

Sebelum melakukan penyuluhan, pelaksana (terdiri dari STIKes 'Aisyiyah, KPA KBB dan PIKR) terlebih dahulu membagikan soal pre test sesuai dengan jumlah perhitungan sampel dengan prosedur Simple Random Sampling, karena populasi bersifat homogen, sehingga didapatkan jumlah sampel 100 siswa/i yang lebih dulu memasuki ruangan aula. Ada beberapa yang sudah mendapatkan leaflet sehingga siswa tersebut tidak termasuk kedalam pengambilan sampel untuk dilakukan uji pre dan post test. Setelah semua siswa siap dan berada dalam aula, 
penyuluhan dibuka dengan sambutan dari Pihak sekolah yang disampaikan langsung oleh Kepala Sekolah MA Al-Mukhtariyah Mande dan Ketua Pelaksana Harian KPA Kabupaten Bandung Barat.

Pada kegiatan inti, yaitu penyuluhan, pembicara memaparkan mengenai Kesehatan Reproduksi Remaja Aqil Baligh, yang terdiri dari : (1) Pengertian Remaja; (2) Pubertas pada Remaja; (3) Pengertian Kesehatan Reproduksi; (4) Pengenalan Sistem Anatomi dan fisiologi alat reproduksi; (5) Risiko Kesehatan Reproduksi; (6) Convention on The Rights of The Child (Hak Reproduksi pada Remaja); dan (7) dan Infeksi Menular Seksual. Selain itu, pada materi pubertas juga disampaikan hal-hal yang harus dilakukan dan tidak boleh dilakukan oleh remaja berkaitan dengan perilaku seksual yang akan menimbulkan risiko reproduksi seperti kehamilan tidak diinginkan, aborsi dan infeksi menular seksual sampai HIV/AIDS.

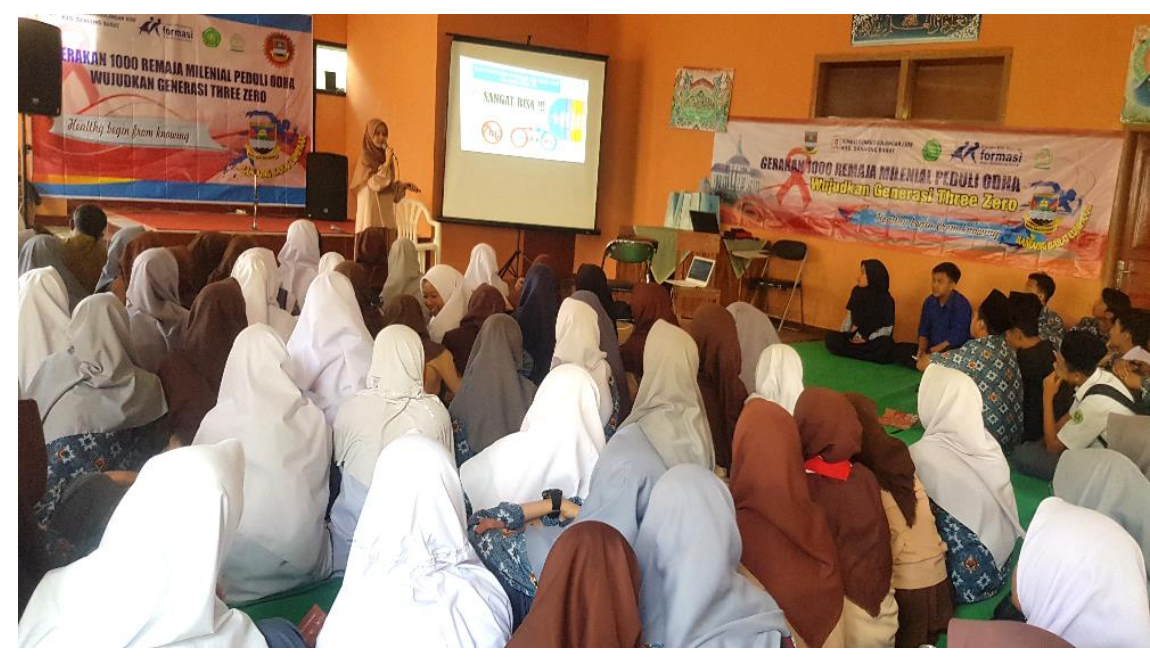

Gambar 3. Penyampaian Materi Kesehatan Reproduksi

Remaja perlu mengetahui kesehatan reproduksi sejak dini supaya memiliki informasi yang benar mengenai proses reproduksi dan mampu terhindar dari berbagai risiko atau masalah reproduksi pada remaja. Dengan informasi yang benar, harapannya remaja akan memiliki sikap dan perilaku yang bertanggung jawab sesuai dengan norma hukum dan agama. Materi yang disampaikan sesuai dengan rekomendasi pengetahuan dasar yang perlu diberikan pada remaja, seperti : pengenalan mengenai sistem, proses dan fungsi alat reproduksi, pendewasaan usia perkawinan pada remaja serta perencanaan kehamilan dengan pasangan, penyakit menular seksual dan HIV/AIDS serta dampaknya pada kesehatan, bahaya penggunaan obat-obatan terlarang, pengaruh media sosial pada perilaku seksual, kekerasan seksual dan hak-hak reproduksi remaja (Adjie, 2013).

Pubertas juga perlu disampaikan kepada remaja, terkait dengan pada masa ini remaja akan mengalami krisis identitas dan kebingunganyang terjadi karena perubahan fisik serta psikologi yang nantinya akan membuat remaja mencari tahu dan mencoba segala sesuatu yang belum diketahuinya termasuk seksual. Hal ini juga disebabkan karena hormon seksual yang mulai aktif pada tubuh remaja sehingga menyebabkan timbulnya dorongan seksual pada diri remaja (Sarwono, 2012). Oleh karena itu, remaja perlu mengetahui hal-hal mengenai pubertas, hak dan kewajiban khususnya dalam perilaku reproduksi sehingga mereka akan mampu berperilaku sesuai dengan norma dan dapat dipertanggungjawabkan.

Materi HIV/AIDS yang disampaikan oleh KPA Kabupaten Bandung Barat, terdiri dari (1) Pengertian HIV/AIDS; (2) Penularan HIV/AIDS; (3) Tanda dan Gejala HIV/AIDS; dan (4) Pencegahan HIV/AIDS. Setelah pemaparan mengenai HIV/AIDS, KPA menayangkan sebuah video yang berhubungan dengan HIV/AIDS dan mengajak remaja supaya melakukan sesuatu yang dapat dipertanggungjawabkan dan menghindari risiko reproduksi terutama HIV/AIDS.

Pengetahuan yang benar dan tepat tentang HIV dan AIDS merupakan salah satu poin penting dalam rangka mencegah penyebaran HIV khususnya pada remaja, karena salah satu 
faktor yang dapat mempengaruhi seorang remaja melakukan seks pranikah disebabkan oleh rasa ingin tahu yang besar untuk mencoba segala hal yang belum diketahui. Hal ini juga merupakan ciri-ciri remaja menurut perkembangan psikologisnya, sehingga perlu adanya pendampingan kesehatan yang komprehensif guna mencegah penyebaran risiko reproduksi khususnya HIV/AIDS pada remaja (Pratiwi \& Basuki, 2011).

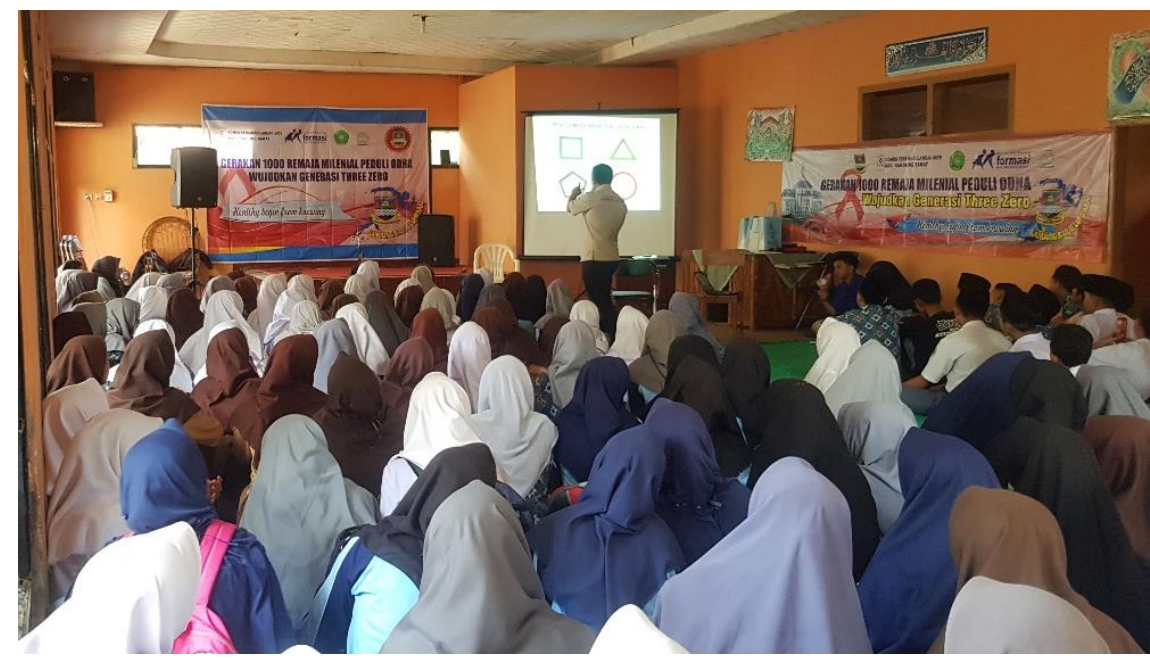

Gambar 3. Penyampaian Materi dan Video Mengenai HIV/AIDS

Efektivitas pemberian media video mengenai HIV/AIDS juga berpengaruh pada peningkatan pengetahuan remaja, sesuai dengan hasil penelitian yang dilakukan oleh Aspiawati (2018) yang berjudul "Pengaruh Pendidikan Kesehatan Berbasis Media Video Animasi Terhadap Pengetahuan Remaja Tentang HIV/AIDS di SMK Negeri 2 Makasar" secara quasi eksperimen, dimana hasilnya menunjukkan adanya peningkatan pengetahuan yang signifikan sebelum dan sesudah diberikan pengetahuan pendidikan kesehatan berbasis video animasi tentang HIV/AIDS. Hal ini biasanya disebabkan karena video animasi lebih menarik perhatian remaja sehingga saat pemberian video semua remaja memperhatikan isi dan pesan yang disampaikan dalam video tersebut (Aspiawati, 2018).

Efektivitas pemberian media video dalam memberikan manfaat untuk meningkatkan pengetahuan juga menjadi capaian kegiatan pengabdian masyarakat yang dilakukan oleh Isvi Rahmatul Mustafa, dkk (2020) bukan hanya hasil penelitian. Salah satu kegiatan dari "Edukasi Gerakan Siswa Anti Narkoba (Geswana) Era Desrupsi 4.0 ini dilakukan dengan pemberian materi dengan menggunakan video, hasil capaian atau evaluasi diketahui secara kualitatif dimana sebagian besar peserta menyatakan bahwa kegiatan tersebut memberikan manfaat dan menambah informasi baru mengenai narkoba (Mustafa et al., 2020).

Hal ini juga dapat dilihat dari perubahan hasil pre dan post test yang sudah dilakukan sebelum dan sesudah pemberian pendidikan kesehatan, dimana Pemberian soal pre dan post test ini untuk mengetahui sejauh mana keberhasilan pemberian pendidikan kesehatan (penyuluhan) terhadap peningkatan pengetahuan siswa/i terhadap materi yang sudah disampaikan. Distribusi frekuensi pre-test dan post-test dapat ditunjukkan pada tabel sebagai berikut :

Tabel 1. Perbedaan Tingkat Pengetahuan Sebelum dan Sesudah Penyuluhan

\begin{tabular}{lccc}
\hline Tingkat Pengetahuan & Pre Test n (\%) & Post Test n (\%) & p* \\
\hline Kurang & 57 & 3 & \\
Baik & 43 & 97 & \\
Mean, SD & $63,8(9,1)$ & $89,4(8,8)$ & 1,89 \\
\hline Total & 100 & 100 & \\
\hline
\end{tabular}

*Uji Wilcoxon signed rank test 
Hasil pada tabel diatas menunjukkan bahwa ada peningkatan pengetahuan yang signifikan dari hasil pre-test dan post-test yang diberikan sebelum dan sesudah penyuluhan dilaksanakan, didukung dengan nilai statistik $\mathrm{p}<0,005$. Hasil ini juga sejalan dengan beberapa penelitian mengenai pengaruh pendidikan kesehatan terhadap peningkatan pengetahuan remaja khususnya tentang kesehatan reproduksi dan HIV/AIDS. Salah satunya adalah penelitian yang dilakukan oleh Buzarudina (2013) hasilnya diperoleh nilai yang signifikan sebebsar 0,000 $(\mathrm{p}<0,05)$, berarti terdapat perbedaan yang bermakna antara skor sebelum dan sesudah penyuluhan, dimana terjadi peningkatan pada tingkat pengetahuan baik dari $0 \%$ menjadi $39,1 \%$. Efektifitas penyuluhan juga dipengaruhi oleh beberapa faktor, diantaranya faktor penyuluh, sasaran dan proses saat pelaksanaan penyuluhan (Buzarudina, 2013).

\section{KESIMPULAN}

Kesimpulan dari kegiatan pengabdian masyarakat yang telah dilakukan dapat diuraikan secara rinci dalam dua poin berikut :

a. Berdasarkan pelaksanaan kegiatan yang telah dilakukan, dapat disimpulkan bahwa pengetahuan yang benar dan tepat tentang Kesehatan Reproduksi, HIV dan AIDS merupakan salah satu poin penting dalam rangka mencegah penyebaran HIV khususnya pada remaja. Kegiatan ini berhasil meningkatkan pengetahuan siswa dan siswi remaja secara signifikan, hal ini juga dipengaruhi oleh penyuluh, ketertiban dan rasa ingin tahu sasaran dan proses pelaksanaan.

b. Penyuluhan ini juga diharapkan bukan hanya berpengaruh pada peningkatan pengetahuan remaja saja, tetapi mampu merubah perilaku dan menjadikan perilaku bertanggungjawab pada kesehatan reproduksinya terutama untuk mencegah penyebaran penularan HIV/AIDS. Diharapkan kedepannya akan terus dilakukan kegiatan serupa khususnya untuk remaja sehingga bukan hanya pengetahuannya saja yang meningkat tetapi perubahan perilakunya juga dapat diawasi secara berkesinambungan guna meningkatkan pengetahuan remaja mengenai Kesehatan Reproduksi dan HIV/AIDS sehingga menjadi salah satu bentuk penanggulangan dan pencegahan HIV/AIDS yang komprehensif mulai dari usia remaja.

\section{SARAN}

Pengabdian lanjutan dari kegiatan ini diharapkan bisa dalam bentuk implikasi dari pencegahan perilaku seksual menyimpang dan menjauhi risiko terinfeksi HIV/AIDS di sekolahsekolah, bukan hanya terfokus ke satu sekolah saja. Sehingga kegiatan ini bukan hanya sebatas sosialisasi tetapi menjadikan aksi nyata remaja sebagai tindak lanjut. Kerjasama dengan pihak lain yang terkait sangat diharapkan untuk terselenggaranya kegiatan serupa yang lebih baik di masa mendatang.

\section{UCAPAN TERIMA KASIH}

Ucapan terimakasih disampaikan kepada Sekolah Tinggi Ilmu Kesehatan 'Aisyiyah Bandung sehingga kegiatan ini dapat terlaksana dengan baik, kepada Komisi Penanggulangan AIDS (KPA) dan Pusat Informasi Konseling Remaja (PIKR) Kabupaten Bandung Barat yang sudah menjadi mitra dan melibatkan STIKes 'Aisyiyah Bandung pada program "Gerakan 1000 Remaja Milenial Peduli ODHA, Wujudkan Generasi Three Zero" di Kabupaten Bandung Barat.

\section{DAFTAR PUSTAKA}

Adjie, J. . S. (2013). Kesehatan Reproduksi Remaja Dalam Aspek Sosial. In The2nd Adolescent Health National Symposia: Current Challenges in Management. Ikatan Dokter Anak Indonesia. http://www.idai.or.id/ 
Aspiawati. (2018). Pengaruh Pendidikan Kesehatan Berbasis Media Video Animasi Terhadap Pengetahuan Remaja tentang HIV/AIDS [Universitas Islam Negeri Alauddin Makasar]. http://repositori.uin-alauddin.ac.id/

Buzarudina, F. (2013). Efektivitas Penyuluhan Kesehatan Reproduksi Remaja Terhadap Tingkat Pengetahuan Siswa Sman 6 Kecamatan Pontianak Timur Tahun 2013. Jurnal Mahasiswa PSPD FK Universitas Tanjungpura, 3(1).

Depkes RI. (2018). Hari AIDS Sedunia, Momen STOP Penularan HIV : Saya Berani, Saya Sehat! Biro Komunikasi Dan Pelayanan Masyarakat, Kementerian Kesehatan RI. https://www.kemkes.go.id/

Kamila, A., Suratmi, T., \& Winidyaningsih, C. (2017). Analisis Perilaku GAY dalam Upaya Pencegahan Infeksi HIV/AIDS di Kabupaten Bandung Barat. Jurnal Bidang Ilmu Kesehatan, 7(1), 4. http://ejournal.urindo.ac.id/index.php/kesehatan/article/view/206

Kemenkes, R. I. (2014). Situasi Kesehatan Reproduksi Remaja. Pusat Data dan Informasi Kementerian Kesehatan RI.

Kementerian Sosial RI. (2018). Kukuhkan 1000 Sahabat Peduli ODHA. Kemensos RI. https://www.kemsos.go.id/

KPA Kabupaten Bandung Barat. (2019). Analisis Situasi IMS, HIV, AIDS Kabupaten Bandung Barat. Mustafa, I. R., Abdillah, M. B., Winata, N. R., Pratama, R., Isnanda, R., Putra, T. D. A., \& Sulistyo, W. D. (2020). Edukasi Gerakan Siswa Anti Narkoba" (Geswana) Era Desrupsi 4.0 di Smp Wahid Hasyim Malang. Dinamisia: Jurnal Pengabdian Kepada Masyarakat, 3(2 SE-Articles). https://doi.org/10.31849/dinamisia.v3i2.3214

Pratiwi, N. L., \& Basuki, H. (2011). Hubungan Karakteristik Remaja Terkait Risiko Penularan Hivaids Dan Perilaku Seks Tidak Aman Diindonesia. Buletin Penelitian Sistem Kesehatan, 14(4 Okt).

Sarwono, S. W. (2012). Psikologi Remaja (Revisi). PT. Raja Grafindo Persada.

WHO. (2019). Adolescent Sexual Reproductive Health. South-East Asir Regional Office WHO. http://www.searo.who.int/ 